\title{
Evaluation of Ionic Osmotica in Succulent and Non-succulent Xero-halophytes Inhabiting Hot Oases
}

\author{
Farghali, K. A. ${ }^{1 *}$, El-Sharkawi H. M. ${ }^{1}$, Rayan A. M. ${ }^{2}$ and Suzan A. Tammam ${ }^{1}$ \\ ${ }^{1}$ Botany and Microbiology Department, Faculty of Science, Assiut University, Egypt, 71516 \\ ${ }^{2}$ Botany and Microbiology Department, Faculty of Science, New Valley University, Egypt
}

\begin{abstract}
This research was carried out at Kharga and Dakhla oases, in the western Egyptian desert. The species investigated include basically those of different ecological affiliations and different life forms, to have comparative indications on the ionic means of adjustment. During winter and summer, the water-soluble ions for both of soil and plants were analyzed. The total osmotic water potential and the share of ionic radicals of plants were also calculated. The data revealed that halophytic species were able to maintain osmotic adjustment due to the accumulation of ions, depending on seasonal and species variations, and the possession of ionic osmotic potential that related to chlorides, sodium and potassium. The seasonality or location has the dominant effect on $\mathrm{Na}^{+}, \mathrm{K}^{+}, \mathrm{Cl}^{-}$and $\mathrm{SO}_{4}^{-2}$ concentrations in halophytes, Suaeda monoica and Cressa cretica, and also affected by the interaction between both factors ( $\mathrm{S} \times \mathrm{L})$ in the case of Zygophyllum coccenium. The ionic osmotic potential of $\mathrm{Na}^{+} / \mathrm{K}^{+}$and $\mathrm{Cl}^{-} / \mathrm{SO}_{4}^{-2}$ ratios for salt tolerance in studying halophytic species were also discussed.
\end{abstract}

Keywords: Ionic, osmotica, succulents, halophytes, hot areas.

\section{INTRODUCTION}

The influence of climate on plants becomes of primary importance for those areas most affected by aridity. In arid and semiarid regions, the aridity depends on the amount of water available and on the temperature which is more relevant to plant life. However, the capabilities of plants to utilize the available water under ionic or non-ionic stresses reflect the magnitude of their adaptability to thrive the severe conditions in their habitats. The ionic stress due to arise of $\mathrm{NaCl}$ in the rooting medium has adverse effects on plant growth and development. Mostly, these effects are osmotic stress, ion toxicity, antagonism and imbalance of ion specificity. Furthermore, the ionic and osmotic effects disturb aerobic metabolism and induce the accumulation of reactive oxygen species (ROS) beyond the plant's capacity for cellular oxidant detoxification, which in turn adversely affects cellular structures and metabolism (Chaves, et al., 2009).

With the accumulation of $\mathrm{NaCl}$ in the leaves of some halophytes and use it as an osmoticum, the downregulation of $\mathrm{Na}^{+}$uptake transporters will be toxic (Katschnig et al., 2015). Accordingly, halophytes will adjust osmotically to soil salinity by accumulating ions mainly sodium and chloride. Therefore, cation transporters and channels exhibited to be involved in $\mathrm{Na}^{+}$ and $\mathrm{K}^{+}$homeostasis in plants (Suzuki et al., 2016b). This means that, the low cytosolic $\mathrm{K}^{+}$concentrations, which participates in many physiological functions in plants, leads to severe metabolism impairment and ended with growth inhibition. Therefore, a high $\mathrm{K}^{+} / \mathrm{Na}^{+}$ ratio can be manipulated by different mechanisms that function to: (1) reduce $\mathrm{Na}^{+}$influx into root cells; (2) compartmentalize $\mathrm{Na}^{+}$into vacuoles; (3) increase $\mathrm{Na}^{+}$ efflux from root cells (Tester and Davenport, 2003; Pardo and Rubio, 2011).
Salt tolerance of many Xero-halophytes in their habitats has mechanisms to survive with salt stress such as osmotic tolerance, ion exclusion, and tissue tolerance (Roy et al, 2014; Munns and Tester2008). These criteria can be evaluated by the osmoionic regulation of water potential by the investigated species. Investigating $\mathrm{Na}^{+}$and $\mathrm{K}^{+}$homeostasis in plants, grown under saline condition, may increase the understanding of salt stress tolerance mechanisms. This can be declared by estimation of the osmotic water potential of $\mathrm{Na}^{+}, \mathrm{Cl}^{-}, \mathrm{K}^{+}$and $\mathrm{SO}_{4}{ }^{-2}$ in plants inhabit hot Egyptian oases. The data obtained, concern this study, for both soil and studied plant are evaluated by statistical analyses.

\section{MATERIAL AND METHOD}

This work was carried out on wild halophytes inhabiting saline areas with soil texture ranged between sandy to silty soil for Kharga (Locations 1-6) and Dakhla (Locations 7-9) oases and adjacent lands in the western desert of Egypt (Map,1). Soils and plants were sampled twice: in mid-winter conditions and in harsh summer climate to cover the seasonal changes. The measured parameters in response to changes in climatic conditions were tabulated (Table, 1). Both soil and plant samples were collected from some sites (stands) which represent its distribution at different habitats in both oases.

\section{Soil samples and collection technique}

Soil samples were collected from the rooting zone of the investigated plants, by digging down around the root zone, from different selected locations. The studied locations were site 1 (Port-Said); site 2 (Ganah); site 3 (Bolaque); site 4 (Sanaa); site 5 (Gazayer); site 6 (South Max); site 7 (Teneida); site 8 (Asmant) and site 9 (Qalamoon). For each site, three replicates of the soil samples (chosen at random) and sampled from surface 


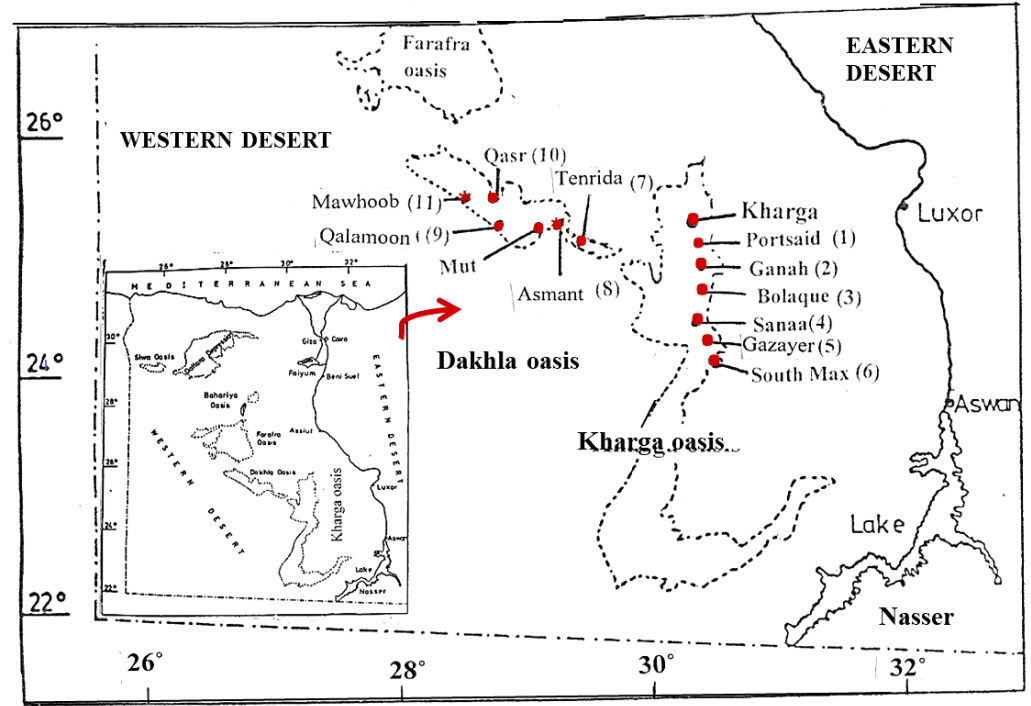

Map (1): The study area and sampling locations.

(0-5 cm), and sub-surface soil (at depth 20-25 cm), then transferred in a clean plastic container to the laboratory. The percentage of water content in the soil samples was calculated according to the following equation:

$$
\% \text { of water content }=\frac{\text { Wet soil-Dry soil }}{\text { Drysoil }} \times 100
$$

\section{Preparation of soil extracts}

Water extract of each air-dried and sieved soil sample was prepared at the ratio of 1:5 (soil/dist. $\mathrm{H}_{2} \mathrm{O}$ ). The soil extracts were kept in the deep freeze until the time of chemical analyses. These analyses include: total soluble salts (TSS); anions, sulphates and chloride, and cations such as sodium and potassium ions. TSS was assessed by evaporation of a soil water extract according to the following the equation:

$$
\% \text { of TSS }=\frac{\text { Wt.of total soluble salts }}{\text { Volume of soil extract }} X \text { dilution } X 100
$$

For anions, sulphate and chloride were determined according to Black et al., (1965) and Jackson (1958), respectively. Meanwhile, sodium and potassium were determined according to the method of Williams and Twine (1960).

\section{Collection of plant samples}

Plant specimens of four native species were collected from their natural habitats in the sites studied, when encountered. The Plant specimens were identified according to Täckholm (1974) and Boulos (1999, 2000, 2002, 2005). The sampled plant species identified as follow: Suaeda monoica Forssk., Salsola imbricate Forssk., (F: Chenopodiaceae), Cressa cretica L.(F: Convolvulaceae) and Zygophyllum coccineum L. (F: Zygophyllaceae). The collected plant materials, branches bearing leaves, were immediately transferred to tightly close plastic containers, which then were transferred to the laboratory for further investigation.
Samples of leaves were washed with distilled water and thoroughly dried on filter paper. For each species, four samples were chosen at random, then oven-dried at $70^{\circ} \mathrm{C}$ for $24 \mathrm{hrs}$. and reweighed to calculate their water content as follows:

$$
\% \text { of water content }=\frac{\text { Fresh Plant Wt-Plant DryWt }}{\text { Fresh Plant Wt. }} \times 100
$$

The relative water content (RWC) of leaves was expressed as a percentage and evaluated according to Weatherly and Barrs (1962) as follow:

$$
R W C=\frac{\text { Fresh Wt of leaf cuts }- \text { Dry Wt of leaf cuts }}{\text { Saturation Wt of leaf cuts-Dry Wt of leaf cuts }}
$$

\section{Preparation of plant extracts for analysis}

After determination of the dry weight, 0.1 gram of finely powdered oven-dried material of each plant sample was transferred to a clean test tube. Ten $\mathrm{ml}$ of bi-distilled water was added and heated to $80-90^{\circ} \mathrm{C}$ in a water bath for a one hour, stirred at intervals and then filtration was done by using filter paper according to El-Sharkawi and Michel (1977). Plant extracts were kept in vials in deep freeze ready for subsequent chemical analyses.

\section{Chemical analyses of cations}

Sodium and potassium were determined by the flame emission technique which is a rapid and sensitive method for the determination of sodium and potassium. The flame photometer method (Williams and Twine, 1960) using Carl Zeiss flame photometer, was applied

\section{Chemical analyses of anions}

Chlorides were measured by $\mathrm{AgNO}_{3}$ titration method as described by Jackson (1958). Sulphates were determined by a turbidemetric method as $\mathrm{BaSO}_{4}$ precipitation by barium chloride and acid sodium chloride requests using a spectrophotometric technique (Black et al., 1965). 
Table (1): Monthly average records of climatic parameters (temperatures, evaporation rate, relative humidity and wind velocity) according to data of Meteorological Station at Kharga oasis.

\begin{tabular}{|c|c|c|c|c|c|c|}
\hline \multirow{3}{*}{ Months } & \multicolumn{6}{|c|}{ Measured parameters } \\
\hline & \multicolumn{3}{|c|}{ Temperature ${ }^{\mathbf{0}} \mathrm{C}$} & \multirow{2}{*}{$\begin{array}{l}\text { Evaporation } \\
\text { rate (ml/day) }\end{array}$} & \multirow{2}{*}{$\begin{array}{c}\text { Relative } \\
\text { humidity (\%) }\end{array}$} & \multirow{2}{*}{$\begin{array}{r}\text { Wind velocity } \\
\text { (knots /hr.) }\end{array}$} \\
\hline & Maximum & Minimum & Daily Mean & & & \\
\hline January & 21.2 & 5.3 & 12.9 & 4.67 & 60 & 3.3 \\
\hline February & 26.5 & 8.2 & 17.2 & 6.05 & 44 & 3.1 \\
\hline Marsh & 24.7 & 10.7 & 17.8 & 11.6 & 38 & 10.4 \\
\hline April & 37.2 & 17.7 & 27.8 & 16.09 & 28 & 6.2 \\
\hline May & 38.1 & 22.1 & 30.2 & 18.29 & 28 & 6.1 \\
\hline June & 40.4 & 25.2 & 33.1 & 21.03 & 32 & 6.2 \\
\hline July & 40.3 & 25.7 & 33.4 & 20.75 & 38 & 5.2 \\
\hline August & 40.6 & 24.3 & 33.1 & 17.72 & 39 & 4.8 \\
\hline September & 37.9 & 23.9 & 30.8 & 17.29 & 45 & 4.2 \\
\hline October & 33.3 & 20.5 & 26.8 & 15.92 & 50 & 8.3 \\
\hline November & 25.8 & 11.8 & 18.7 & 8.73 & 66 & 6 \\
\hline December & 26.3 & 11.2 & 18.5 & 8.57 & 61 & 2.8 \\
\hline Annual average & 32.7 & 17.3 & 25 & 13.9 & 44.1 & 5.6 \\
\hline
\end{tabular}

Determination of osmotic potential of plant extracts and computation of the actual O.P.

The cryoscopy method of Walter (1949) was used for determination water potential by using Beckman differential thermometer (calibrated at $0.01^{\circ} \mathrm{C}$ ) as illustrated by Slatyer and Mcllory (1961). The total osmotic potential of the cell sap was calculated according to EL-Sharkawi and Abdel Rahman (1974).

\section{Calculation of partial osmotic potential (POP)}

The estimation of partial osmotic potential for different ions of plant extracts (chlorides, sulphates, sodium and potassium) was calculated according to the following equation (Kramer and Boyer, 1995):

$$
P O P(\text { of ions })=\frac{\text { Ion con. }\left(\mathrm{gL}^{-1}\right) \times 2.24}{\text { A.Wt of Ion or group }}-M P a
$$

Where A.Wt, is atomic weight; MPa represents water potential.

\section{Statistical evaluation of experimental data}

The effects of single factors (season or location) and their interaction $(\mathrm{S} \times \mathrm{L})$ on the contents of ions in different species were evaluated statistically by the analysis of variance ( $F$ test). The relative role of every single factor and their interaction in the total response was determined by using the coefficient of determination $\left(\eta^{2}\right)$ to indicate the degree of control of the factor on the parameter tested (Ostle, 1963 and Ploxinki, 1969) as applied by EL-Sharkawi and Springuel (1977). A simple linear correlation coefficient (r) between ion concentrations in soils with their equivalents in plants was tested according to Ostle (1963).

\section{RESULTS}

\section{Physical and chemical characteristics of the soil \\ Soil water content (SWC)}

Soil water content at the different locations studied was estimated at both soil surfaces $(0-5 \mathrm{~cm})$ and subsurface $(20-25 \mathrm{~cm})$.The SWC at the surface (Figure, 1) was higher in the winter and reached to $6.2 \%$ of the oven dry soil (site 4), and the lowest value $0.04 \%$ was found at site 2 . In the sub-surface soil, the water content showed relatively higher levels in winter at all locations. The highest percentage of SWC $(22.7 \%$ of the dry soil) was observed at site 8 followed by $17.48 \%$ at site 4 . At site 1 , the water content was exceptionally higher in summer $(17.2 \%)$ than in winter $(13.23 \%)$. The lowest percentage $(0.4 \%)$ was found at site 2 in the two seasons at both soil surface and sub-surface.

From the ANOVA (Table, 2), the effects of season, location and their interaction on SWC were significant at both soil surface and sub-surface soil. The season effect had the dominant role on SWC in the soil surface $\left(\eta^{2}=0.44\right)$, while the effect of location had the dominant role in soil water content at sub-surface soil $\left(\eta^{2}=0.60\right)$.

Total soluble salts (TSS)

In both seasons, the total soluble salts (as \% of dry wt.) were higher in surface soil than in sub-surface in most locations (Figure, 1). In soil surface, TSS \% during winter was higher than in summer and reached $21.99 \%$ at site 8 , while the lowest value $(0.81 \%)$ was found on site 4 . In sub-surface soil, the highest value $(7.48 \%)$ was detected at site 7 in winter; whereas the lowest value $(0.08 \%)$ was found at site 2 in summer.

\section{Soil $p H$}

The soil $\mathrm{pH}$ at all locations was always observed to be alkaline and slightly increased in winter in both soil levels. At the soil surface, the maximum $\mathrm{pH}$ value was 8.77 at site 2 and the minimum was 7.24 at site 8 . In the sub-surface, the highest value was 8.94 at site 1 and the lowest value was 7.41 at site 8 .

\section{Cations}

Sodium

Sodium is considered the most abundant cation which has the highest content among investigated 
cations (Figure, 2). In both seasons, sodium content at soil surface was higher than that at sub-surface soil, except site 8 during summer. At soil surface, the content of $\mathrm{Na}^{+}$in winter was higher than that in the summer, where site 8 recorded the highest content of $\mathrm{Na}^{+}(75.83 \mathrm{mg} / \mathrm{g}$. dry wt.) during winter. At subsurface soil, the content of $\mathrm{Na}^{+}$varied from one location to another. At site 7 recorded the highest site 8 observed the highest content (17.35 mg/g. dry wt.) during summer, while site 2 had the lowest $\mathrm{Na}^{+}$content $(0.03 \mathrm{mg} / \mathrm{g}$. dry wt.) in both seasons.

\section{Potassium}

In general, potassium content at surface was higher than that at sub-surface soil, and both soils contained more $\mathrm{K}^{+}$during the winter season (Figure, 2 ). At soil surface, it was observed that site 1 had the highest content of $\mathrm{K}^{+}(9.08 \mathrm{mg} / \mathrm{g}$. dry. wt. $)$ in winter and site 2 gave the lowest content $(0.11 \mathrm{mg} / \mathrm{g}$. dry wt.) during summer. The sub-surface soil at site 9 exhibited the highest value of $\mathrm{K}^{+}(6.66 \mathrm{mg} / \mathrm{g}$. dry wt.) in winter whereas the lowest value $(0.03 \mathrm{mg} / \mathrm{g}$. dry wt. $)$ existed at site 2 in summer.

\section{Anions}

\section{Chloride}

Apparently, chloride ion was the major anion existing in the soil extract. This was clearly observed at soil sur face (Figure, 3), where in general, the content of $\mathrm{Cl}^{-}$ ion was greater than at sub-surface soil in both season, apparently due to high water evaporation. Moreover, sub-surface accumulates chloride in winter, (probably due to leaching from the surface). The highest content $(51.9 \mathrm{mg} / \mathrm{g}$.dry wt.) was found at site 2 and site 9 . At sub-surface soil, the highest content of $\mathrm{Cl}^{-}$(30.34 $\mathrm{mg} / \mathrm{g}$.dry wt.) was found at site 8 in summer and at site 7 in winter (Dakhla oasis). The lowest value (0.89 $\mathrm{mg} / \mathrm{g}$.dry wt.) existed at sites $2 \& 4$.

\section{Sulphate}

Sulphate content in soil extract recorded low values at both soil surface and sub-surface soil in the two seasons. Site 1 exhibited the highest content $(0.78 \mathrm{mg} / \mathrm{g}$ dry wt.) of $\mathrm{SO}_{4}{ }^{2-}$ during summer, and site 8 recorded the highest content $(0.6 \mathrm{mg} / \mathrm{g}$.dry wt.) during winter, the lowest content $(0.02 \mathrm{mg} / \mathrm{g}$.dry wt.) was observed at site 2 in both seasons at both soil levels (Figure, 3 ).

\section{Plant water content}

Plant water content was determined as a percentage of fresh weight (Table, 4). It was found that water content in most investigated plants was high. In halophytic plants such as Salsola, there were no noticeable changes in water content during both seasons at nearly all sites inhabited. Zygophyllum, Cressa and Suaeda showed a slight difference in water content in both seasons. Water content was higher in winter than in summer in most plants. Meanwhile water content was higher in summer than in winter in Zygophyllum, and Salsola. Zygophyllum had the highest average water content $(77.16 \%)$ followed by Suaeda $(77.14 \%)$.

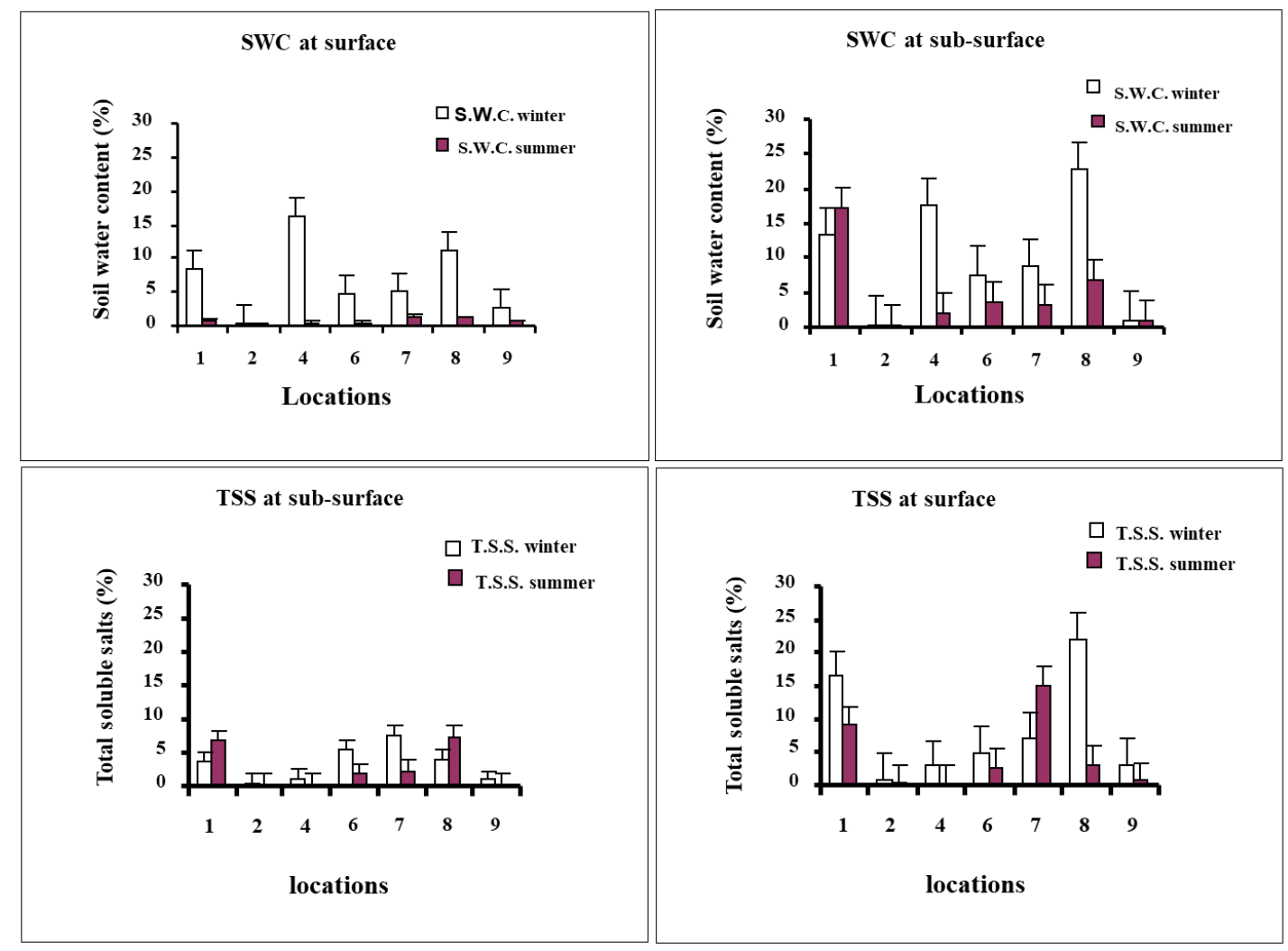

Figure (1): The average percentages of soil water content (SWC), and total soluble salts (TSS) in surface and subsurface soils at different locations during winter and summer. 
Table (2): Significance level of the effects of seasons (S), location (L) and their interaction ( $\mathrm{S} \times \mathrm{L})$ on volumetric soil water content at soil surface and at sub-surface soil horizon using ANOVA test.

\begin{tabular}{llll}
\hline \hline Soil water content & Source of variance & F value $^{\dagger}$ & $\mathbf{\eta}^{\mathbf{2}}$ \\
\hline & Seasons & $8840.308^{* *}$ & 0.40 \\
At surface $\mathbf{( 0 - 5 c m )}$ & Locations & $912.6667^{* *}$ & 0.27 \\
& S x L & $969.1567^{* *}$ & 0.29 \\
At sub-surface & Seasons & $325.8487^{* *}$ & 0.14 \\
$\mathbf{( 2 0 - 2 5} \mathbf{~ c m})$ & locations & $232.1669^{* *}$ & 0.60 \\
& S x L & $100.3124^{* *}$ & 0.26 \\
\hline \hline
\end{tabular}

${ }^{\uparrow *}$ Significance level at $p<0.05$ level; $* *$ Significance level at $p<0.01$.

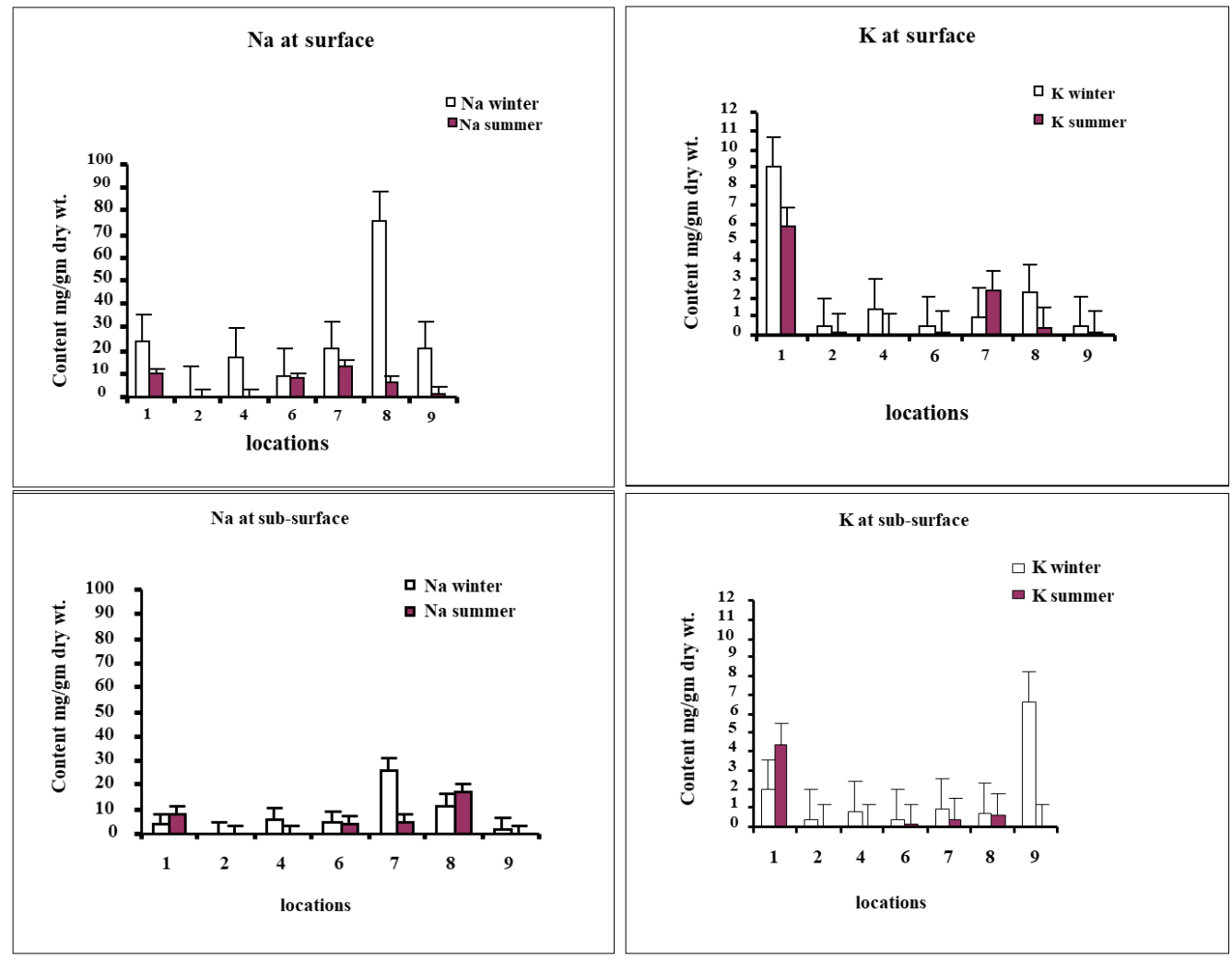

Figure (2): The average content (mg/gm dry soil) of cations $\mathrm{Na}^{+}$and $\mathrm{K}^{+}$at surface and sub-surface soils at different locations during winter and summer.

\section{Relative water content}

Relative water content (RWC) of investigating species at their native location was determined (as a percentage) in winter and summer (Figure, 4). In a xerophyte succulent plant (Zygophyllum) there was a high RWC (site 3,74.3\%) during winter and slightly decreased during summer. This means that this species had sufficient water and don't suffer from water deficit. Both Suaeda, and Prosopis species had a moderate percentage of RWC (more than 50\%), while other plants, such as Salsola and Cressa, studied species had a low percentage of RWC (less than 50\%). This can be explained in such context that such species are suffering from a shortage of water and therefore a water deficit is developed.

\section{Correlation between relative water content and soil water content}

In (Table, 3) the correlation between relative water content in investigated plants and soil water content was nonsignificant in Salsola species during summer at both soils surface and sub-surface. This may indicate that relative water content is not dependent on the soil water content and the plant has its mean of water conservation (probably through osmotic adjustment). On the other hand, correlation between relative water content and soil water content was significantly positive especially in Zygophyllum at both soil levels during both seasons. This may indicate that relative water content is highly dependent on soil water content in such species. 


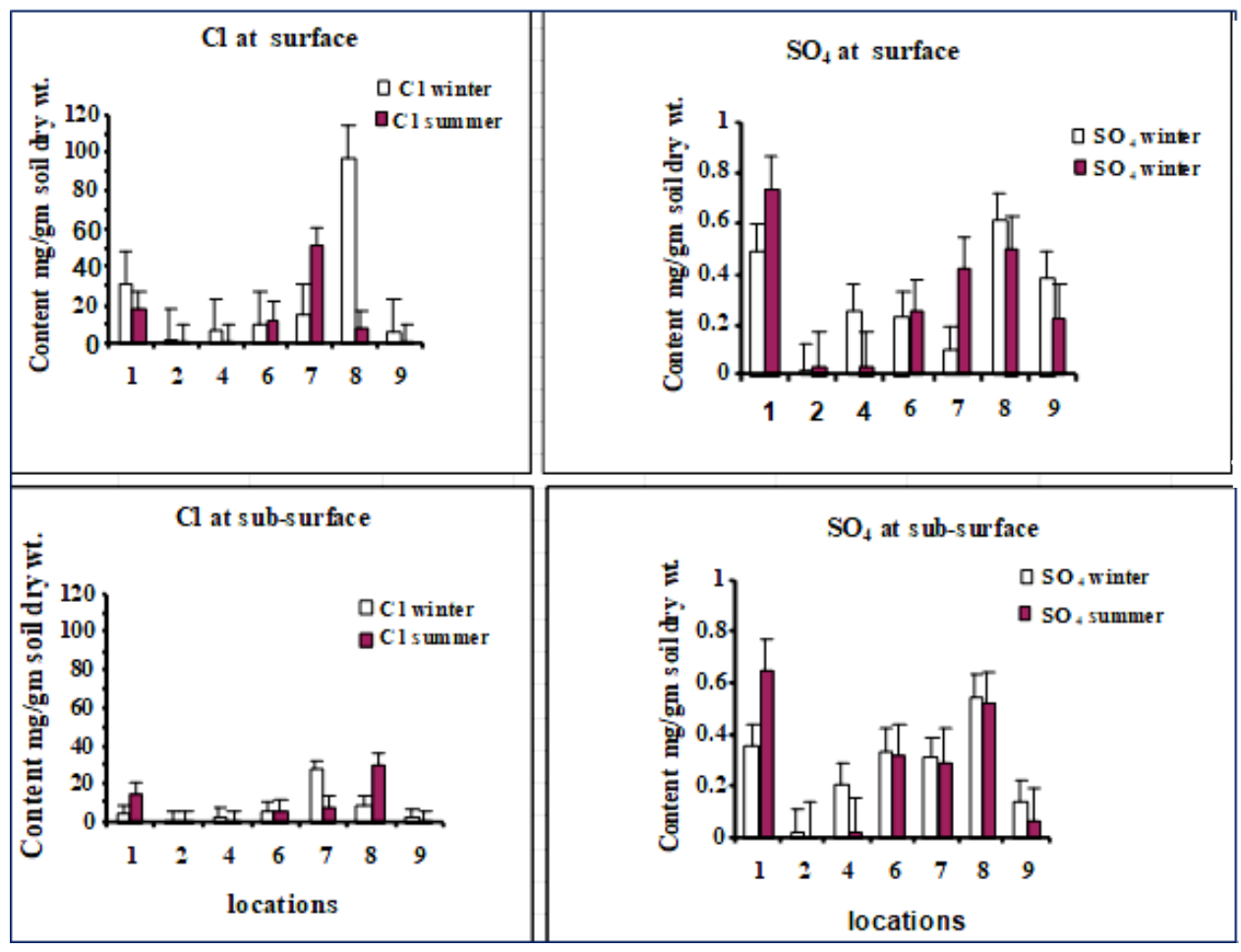

Figure (3): The average content (mg/gm dry soil) of anions (chlorides $\mathrm{Cl}^{-}$and sulphates $\mathrm{SO}_{4}{ }^{2-}$ ) at surface and sub-surface soils at different studied locations during winter and summer.

Table (3): Correlation coefficients (r) values between relative water content (RWC) in investigated plants and soil water content, at the surface and sub-surface in their habitats, during both seasons.

\begin{tabular}{lcccc}
\hline \multirow{2}{*}{ Studied Plant Species } & \multicolumn{4}{c}{ Soil samples } \\
\cline { 2 - 5 } & \multicolumn{2}{c}{ At Surface } & \multicolumn{2}{c}{ At Sub-surface } \\
\cline { 2 - 5 } & Winter & Summer & Winter & Summer \\
\hline Zygophyllum & $0.934^{* *}$ & $0.952^{* *}$ & $0.969^{* *}$ & $0.931^{* *}$ \\
coccineum & -0.362 & $-0.869^{* *}$ & -0.154 & $-0.629^{* *}$ \\
Salsola imbricata & -0.342 & -0.644 & -0.423 & 0.493 \\
Suaeda monoica & -0.447 & 0.031 & -0.521 & -0.296 \\
Cressa cretica & * Significance level at $p<0.05$ level; & ** Significance level at $p<0.01$. & & \\
\hline
\end{tabular}

\section{Elemental constituents in plant sap}

\section{Sodium}

Halophytic plants, in general, have higher concentration of sodium $\left(\mathrm{Na}^{+}\right)$compared to succulent species as shown in (Figure, 5). The accumulation of sodium occurred during winter and reached a maximum value of $66.29 \mathrm{mg} / \mathrm{ml}$ sap in Salsola (as a halophytic species) at site 4. Both Cressa and Suaeda had higher $\mathrm{Na}^{+}$concentration in summer than that in winter. In Zygophyllum as a succulent species a relatively low concentration of $\mathrm{Na}^{+}$was observed and slightly changed during the two seasons in all studied locations. Exceptionally, the highest $\mathrm{Na}^{+}$concentration in the same plant was $20.65 \mathrm{mg} / \mathrm{ml}$ sap at site 4 during winter.

\section{Potassium}

A general trend in the investigated halophytic plants was their tendency to accumulate $\mathrm{K}^{+}$during winter
(Figure, 6). Halophytic plants contained the highest amounts of $\mathrm{K}^{+}(33.96 \mathrm{mg} / \mathrm{ml}$ sap) e.g. Salsola. A succulent xerophyte $Z$. coccineum contained amount of $\mathrm{K}^{+}$ranging between $0.83-7.89 \mathrm{mg} / \mathrm{ml}$ sap particularly in winter. The accumulation of $\mathrm{K}^{+}$varied among all investigated plants during winter. In summer, there were slight changes in $\mathrm{K}^{+}$concentration in species at different sites. Zygophyllum contained low $\mathrm{K}^{+}$ concentration during the two seasons. In winter, the highest concentration $(7.89 \mathrm{mg} / \mathrm{ml} \mathrm{sap})$ was observed at site 2 and the lowest $(0.83 \mathrm{mg} / \mathrm{ml} \mathrm{sap})$ was found at site 5 . In summer, $\mathrm{K}^{+}$concentration ranged between $0.86-2.08 \mathrm{mg} / \mathrm{ml} \mathrm{sap}$.

The ANOVA test in (Table, 4) showed that seasons, locations and their interaction had significant effects on $\mathrm{Na}^{+}$and $\mathrm{K}^{+}$concentrations in most plants. The effect of seasons on changes in $\mathrm{Na}^{+}$concentration had a dominant role in Suaeda and Cressa $\left(\eta^{2}=0.69\right.$ and 0.79 , respectively). Likewise, seasonal effect had a 


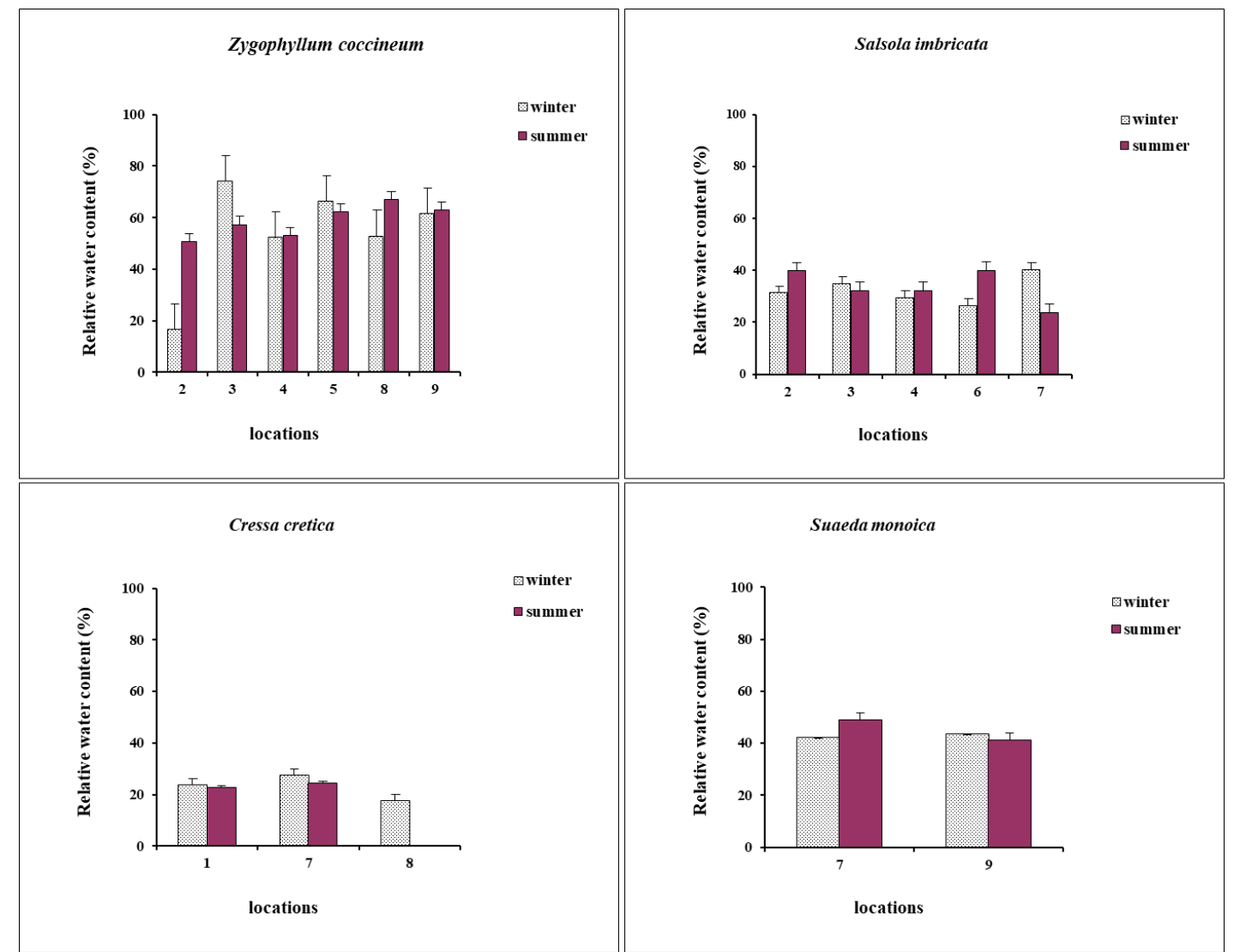

Figure (4): The average percentage of relative water content of investigated species at their locations during winter and summer seasons.

Table (4): Significance level of the effects of seasons (S), location (L) and their interaction (S x L) on cation concentrations $\left(\mathrm{Na}^{+}\right.$and $\left(\mathrm{K}^{+}\right)$of investigated species at Kharga and Dakhla regions, by means of one-way ANOVA test.

\begin{tabular}{llcccc}
\hline \hline \multirow{2}{*}{ Studied Plant Species } & \multicolumn{5}{c}{ Cation concentration } \\
\cline { 2 - 6 } & Source of variance & $\begin{array}{c}\text { F value for } \\
\mathbf{N a}^{+}\end{array}$ & $\eta^{2}$ & $\begin{array}{c}\text { F value for } \\
\mathbf{K}^{+}\end{array}$ & $\eta^{2}$ \\
\hline \multirow{3}{*}{ Zygophyllum coccineum } & Seasons & $5.51^{*}$ & 0.18 & $57.12^{* *}$ & 0.34 \\
& Locations & 1.48 & 0.24 & $10.62^{* *}$ & 0.31 \\
& S x L & $3.50^{*}$ & 0.58 & $11.82^{* *}$ & 0.35 \\
Salsola imbricata & Seasons & $10.9^{* *}$ & 0.13 & $36.26^{* *}$ & 0.19 \\
& Locations & $7.68^{* *}$ & 0.38 & $19.86^{* *}$ & 0.42 \\
\multirow{3}{*}{ Suaeda monoica } & S x L & $9.85^{* *}$ & 0.49 & $18.33^{* *}$ & 0.39 \\
& Seasons & $7.21^{*}$ & 0.69 & $40.07^{* *}$ & 0.64 \\
Cressa cretica & Locations & 1.82 & 0.18 & $20.66^{* *}$ & 0.33 \\
& S x L & 1.35 & 0.13 & 1.82 & 0.03 \\
& Seasons & $21.98^{* *}$ & 0.79 & 3.7 & 0.08 \\
& Locations & 2.55 & 0.09 & $38.32^{* *}$ & 0.87 \\
\hline \hline
\end{tabular}

* Significance level at $p<0.05$ level; ** Significance level at $p<0.01$.

dominant role on $\mathrm{k}^{+}$concentration in Suaeda $\left(\eta^{2}=\right.$ 0.64), while the effect of their) interaction ( $\mathrm{S} \times \mathrm{L})$ had an equal share with the effect of seasons on $\mathrm{K}^{+}$ concentration in the case of Zygophyllum $\left(\eta^{2}=0.35\right)$. In parallel, the ( $\mathrm{S} \times \mathrm{L})$ interaction plays a dominant role on $\mathrm{Na}^{+}$concentration that detected in Salsola and Zygophyllum $\left(\eta^{2}=0.49 \& 0.58\right.$ respectively $)$. However, the influence of locations on $\mathrm{K}^{+}$ concentration showed a dominant role (evaluated by $\eta^{2}$ values) in both Cressa and Salsola.

\section{Anion}

\section{Chloride $\left(\mathrm{Cl}^{-}\right)$}

Chloride ion concentration in plant sap is shown in (Figure, 7). In general, halophytes had higher $\mathrm{Cl}^{-}$ concentration in succulent species. Also, the concentration of $\mathrm{Cl}^{-}$in most species was higher in summer than in winter with some exceptions. In summer, the maximum chloride concentration $(85.03 \mathrm{mg} / \mathrm{ml} \mathrm{sap})$ was found in Cressa at site 7 followed by Suaeda as halophytic species. While Zygophyllum (succulent 
species) had high $\mathrm{Cl}^{-}$concentration $(31.06 \mathrm{mg} / \mathrm{ml} \mathrm{sap})$ was detected at site 8 .

Data from $\mathrm{F}$ test in (Table, 5) showed a clearly significant role of seasons, locations and their interactions on chloride ion concentration in most species. Change of seasons had a dominant role in affecting chloride ion concentration in most plants and the effect of $\left(\begin{array}{lll}S & \mathrm{~L}\end{array}\right)$ interaction was subdominant.

\section{Sulphate $\left(\mathrm{SO}_{4}{ }^{2-}\right)$}

A general pattern of sulphate accumulation was noticed in the most studied plants during summer (Figure, 8). In winter, halophytes and succulent species had high $\mathrm{SO}_{4}{ }^{2-}$ concentration. Cressa at site 1 had the highest $\mathrm{SO}_{4}{ }^{2-}$ concentration $(4.45 \mathrm{mg} / \mathrm{ml} \mathrm{sap})$. Zygophyllum recorded a moderate $\mathrm{SO}_{4}{ }^{2-}$ concentration during both studied seasons that ranged between (0.67- $3.43 \mathrm{mg} / \mathrm{ml} \mathrm{sap})$. Also, Suaeda species had a moderate range of $\mathrm{SO}_{4}{ }^{2-}$ concentration detected during summer and a low range of $\mathrm{SO}_{4}{ }^{2-}$ concentration in winter. On the other hand, the rest species had a low $\mathrm{SO}_{4}{ }^{2-}$ concentration.

From ANOVA (Table, 5) the effect of either seasons or locations and their interaction on measured $\mathrm{SO}_{4}{ }^{2-}$ concentration was significant in all investigated species. Seasonal variation plays a dominant role in $\mathrm{SO}_{4}{ }^{2-}$ ion in most studied species, except in Zygophyllum where ( $\mathrm{S} \times \mathrm{L})$ interaction had a major role $\left(\eta^{2}=0.47\right)$. Locations had a subdominant role in most plants.

Correlation of investigating plants and ions in surface soil

The data in table (6a) showed that, Cressa had a widely dominant positive correlation with $\mathrm{K}^{+}$content in both seasons, with $\mathrm{Na}^{+}$in summer, with $\mathrm{SO}_{4}{ }^{2-}$ in winter and only one negative correlation with $\mathrm{SO}_{4}{ }^{2-}$ in summer. Moreover, Salsola had a dominant positive correlation with $\mathrm{Cl}^{-}$and $\mathrm{Na}^{+}$in summer, with $\mathrm{SO}_{4}{ }^{2-}$, $\mathrm{K}^{+}$in winter. Meanwhile, Suaeda had a dominant positive correlation with $\mathrm{SO}_{4}{ }^{2-}$ in summer and with $\mathrm{K}^{+}$ in both seasons. On the other hand, Zygophyllum had a dominant negative correlation with $\mathrm{Cl}^{-}, \mathrm{SO}_{4}{ }^{2-}$ and $\mathrm{K}^{+}$in winter and positive correlations with $\mathrm{Cl}^{-}, \mathrm{K}^{+}$\& $\mathrm{Na}^{+}$in summer.

Ionic correlation of investigated plants and ions in sub-surface soil

Apparently, Cressa had a dominant positive correlation with $\mathrm{K}^{+}$in both seasons (Table $6 \mathrm{~b}$ ). A sub-dominant negative correlation was recorded with $\mathrm{SO}_{4}{ }^{2-}$ in summer only. In parallel, Suaeda had a dominant positive correlation with $\mathrm{K}^{+}$that recorded in summer and a negative correlation in winter. Likewise, Zygophyllum had a dominant negative correlation with $\mathrm{Cl}^{-}, \mathrm{SO}_{4}{ }^{2-}$ and $\mathrm{K}^{+}$during winter, and a sub-dominant positive correlation with $\mathrm{Cl}^{-}, \mathrm{Na}^{+}$, and $\mathrm{K}^{+}$in summer.

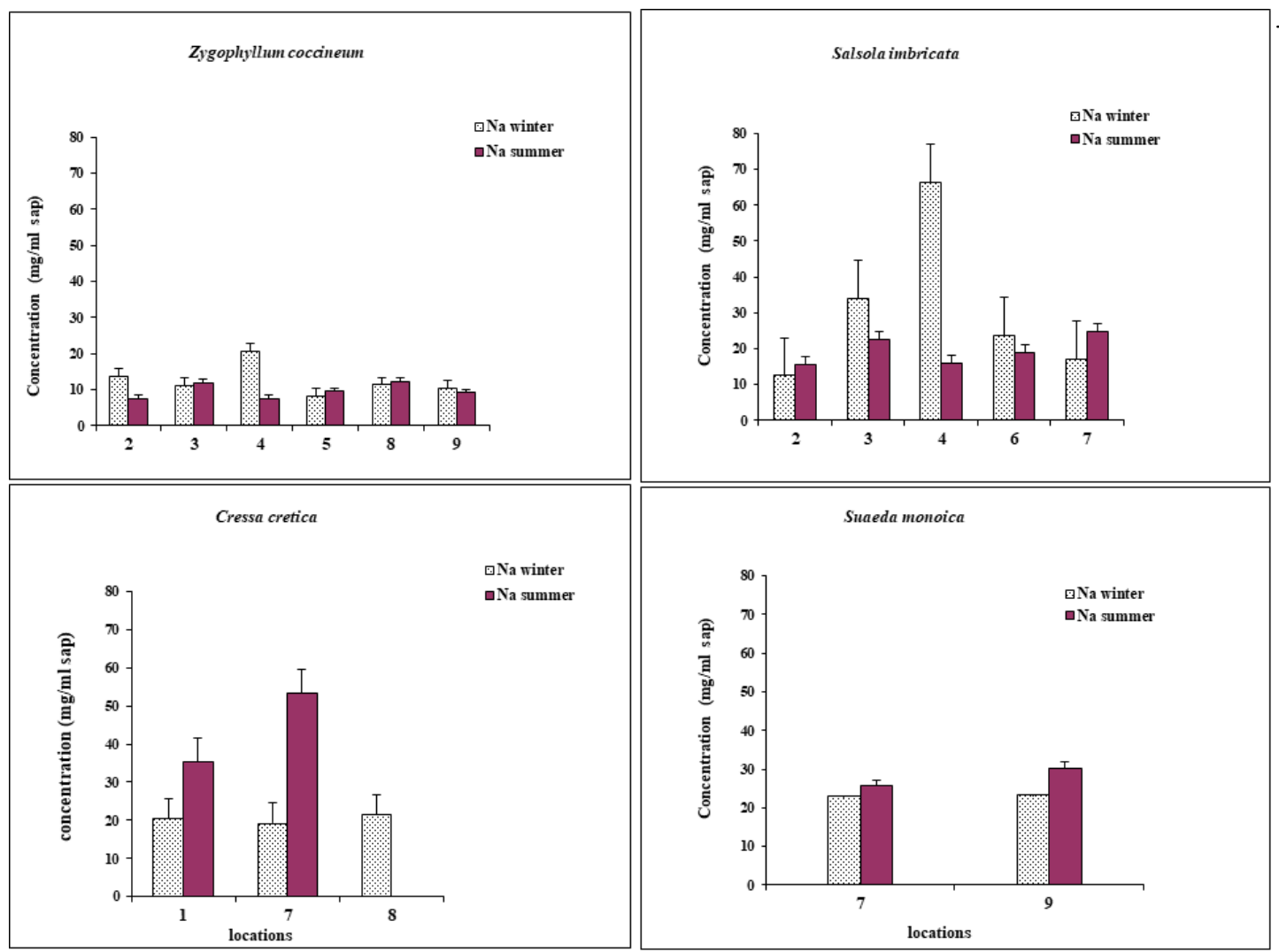

Figure (5):-The average concentration $\left(\mathrm{mg} / \mathrm{ml}\right.$ sap) of sodium ion $\left(\mathrm{Na}^{+}\right)$in investigated species at different studied locations during winter and summer seasons. 


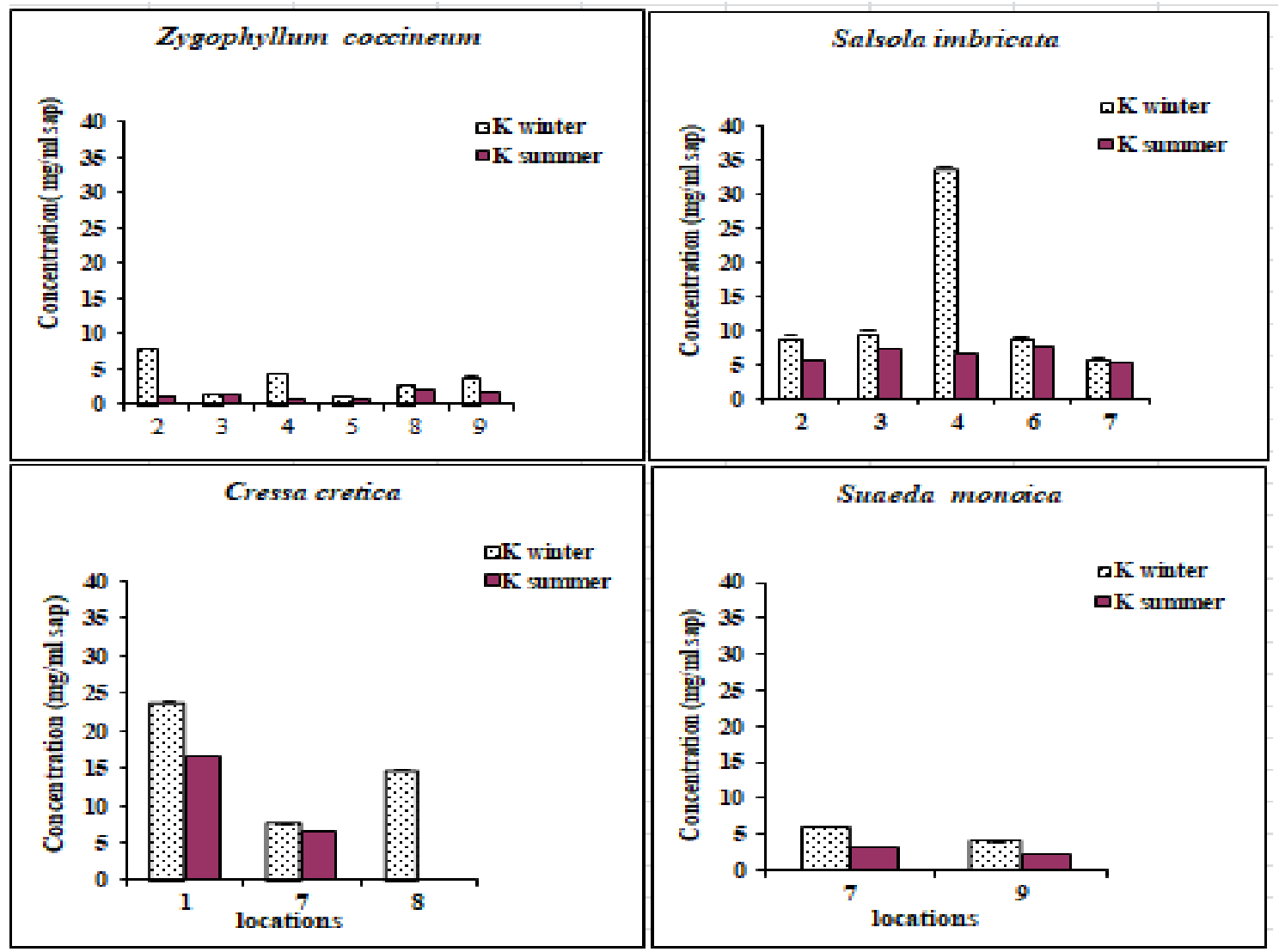

Figure (6): The average concentration $(\mathrm{mg} / \mathrm{ml} \mathrm{sap})$ of potassium ion $\left(\mathrm{K}^{+}\right)$in investigated species at different studied locations during winter and summer seasons.
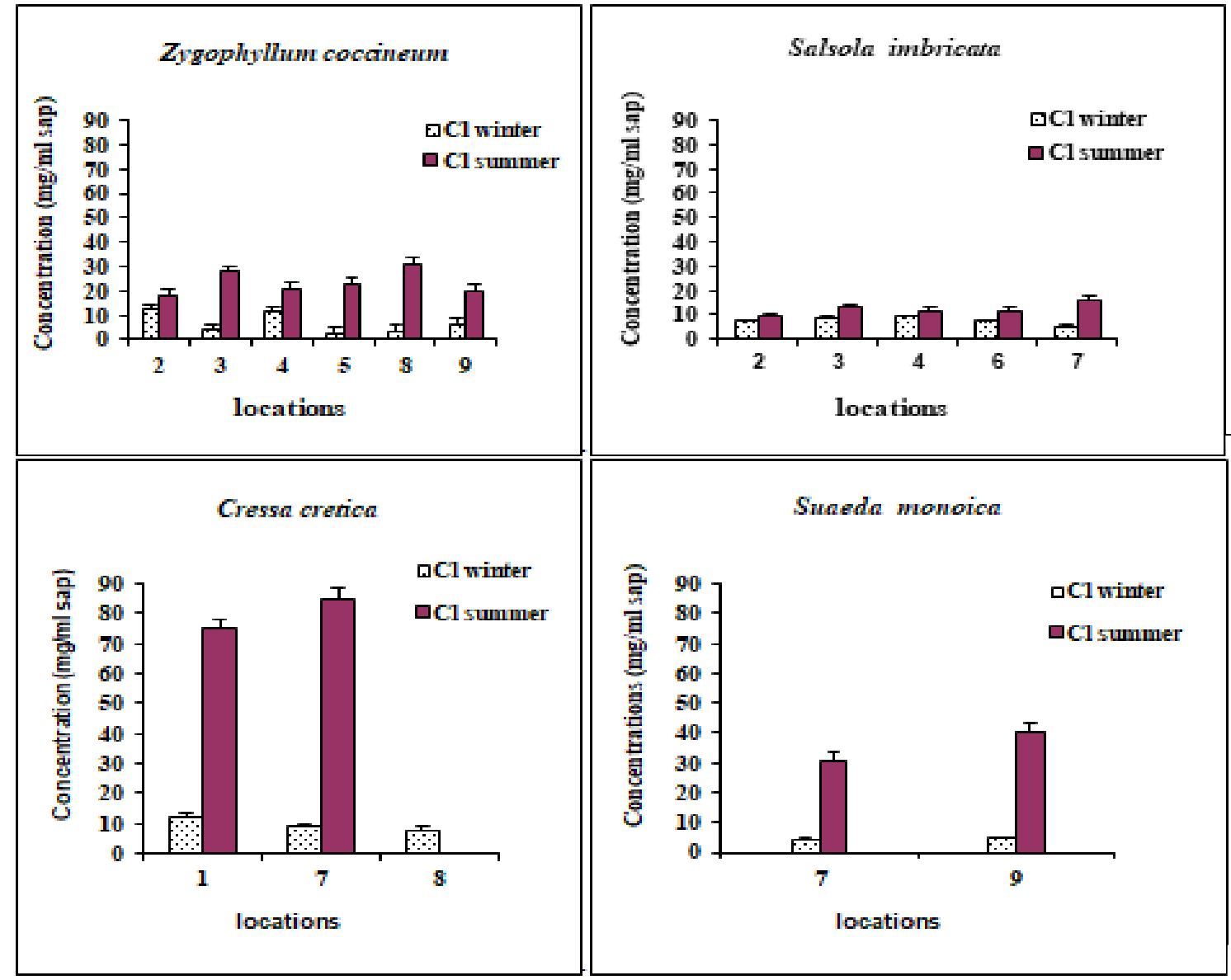

Figure (7): The average concentration ( $\mathrm{mg} / \mathrm{ml}$ sap) of chloride ions $\left(\mathrm{Cl}^{-}\right)$in investigated species at different studied locations during winter and summer seasons. 
Table (5): Significance level of the effects of seasons (S), location (L) and their interaction (S x L) on anion concentration $\left(\mathrm{Cl}^{-} \& \mathrm{SO}_{4}{ }^{2-}\right)$ of investigated species at Kharga and Dakhla regions, using ANOVA test.

\begin{tabular}{|c|c|c|c|c|c|}
\hline \multirow{3}{*}{$\begin{array}{l}\text { Studied Plant } \\
\text { species }\end{array}$} & \multicolumn{5}{|c|}{ Anion concentration } \\
\hline & \multirow{2}{*}{ Source of variance } & \multicolumn{2}{|c|}{$\mathrm{Cl}^{-}$} & \multicolumn{2}{|c|}{$\mathrm{SO}_{4}{ }^{2-}$} \\
\hline & & $\mathbf{F}$ & $\eta^{2}$ & $\mathbf{F}$ & $\eta^{2}$ \\
\hline \multirow{3}{*}{ Z. coccineum } & Seasons & $264.79^{* *}$ & 0.8 & $11.22^{* *}$ & 0.12 \\
\hline & Locations & 1.97 & 0.03 & $7.49^{* *}$ & 0.41 \\
\hline & $\mathrm{S} \times \mathrm{L}$ & $11.41^{* *}$ & 0.17 & $8.49^{* *}$ & 0.47 \\
\hline \multirow{4}{*}{ S. imbricata } & Seasons & $124.26^{* *}$ & 0.64 & $73.91^{* *}$ & 0.6 \\
\hline & Locations & $4.6^{* *}$ & 0.1 & $11.44^{* *}$ & 0.37 \\
\hline & $\mathrm{S} \times \mathrm{L}$ & $12.5^{* *}$ & 0.26 & 1.06 & 0.03 \\
\hline & Seasons & $20.36^{* *}$ & 1 & $80.32^{* *}$ & 0.91 \\
\hline \multirow[t]{2}{*}{ S. monoica } & Locations & 0.03 & 0 & $5.63^{*}$ & 0.07 \\
\hline & $\mathrm{S} \times \mathrm{L}$ & 0.04 & 0 & 1.92 & 0.02 \\
\hline \multirow{3}{*}{ C. cretica } & Seasons & $46.33^{* *}$ & 0.99 & $8.16^{*}$ & 0.88 \\
\hline & Locations & 0.11 & 0 & 0.31 & 0.04 \\
\hline & $S \times L$ & 0.45 & 0.01 & 0.77 & 0.08 \\
\hline
\end{tabular}

*Significance level at $p<0.05$ level; ** Significance level at $p<0.01$.
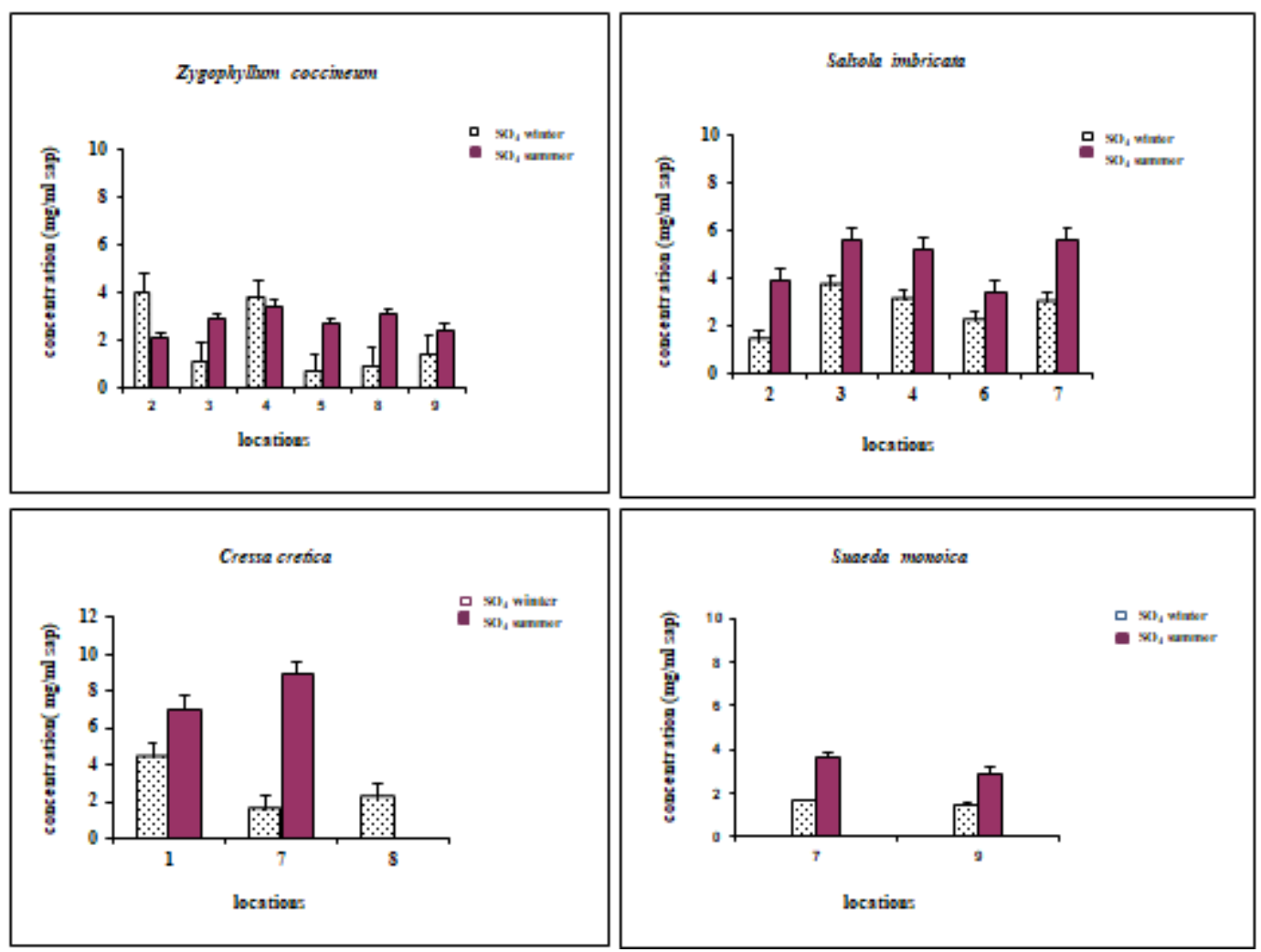

Figure (8): The average concentration ( $\mathrm{mg} / \mathrm{ml} \mathrm{sap})$ of sulphate ions $\left(\mathrm{SO}_{4}{ }^{2-}\right)$ in investigated species at different studied locations during winter and summer seasons.

\section{Total and partial osmotic potential}

The total osmotic potential (TOP), of investigated plants, revealed the potential ability of the plants for osmotically adjusted during winter (Table 7). Suaeda exhibited the highest average TOP during winter. Meanwhile, the average of TOP in Cressa was high during summer, whereas the lowest value was observed in Zygophyllum.

The major ions that generally affect plant osmotic potential in a high percentage were chloride, sodium, and potassium, whereas the minor ion affecting plant osmotic potential with a low percentage is sulphates. In 
most investigated species, sodium ion was the major ion in osmoregulation reached $17 \%-29 \%$ in winter and $19 \%-36 \%$ during summer. The same was true in the case of chloride ion which had a relatively greater role in osmoregulation. It contributes high \% of total osmotic pressure especially in summer season $(24 \%$ $42 \%)$ but, only $(4 \%-16 \%)$ in winter. This was demonstrated in Zygophyllum, Cressa, Suaeda. Chloride ion had a moderate role in osmoregulation (4\% during winter and $13 \%$ during summer).
In most investigated species, potassium ion was contributed a relatively moderate percentage of TOP in winter which ranged from 4 to $12 \%$; however, in summer it recorded a lower percentage $(2 \%-7 \%)$. Apparently, TOP of $\mathrm{NaCl}$ in Cressa was the highest among the investigated species. On the other hand, the osmotic potential ratio of $\mathrm{Na}^{+} / \mathrm{K}^{+}$was tended to a maximum in Suaeda in summer. The same was true in case of $\mathrm{Cl}^{-} / \mathrm{SO}_{4}^{-2}$ ratios in both Suaeda and Zygophyllum for the same season.

Table (6): Correlation coefficient (r) values between ion concentrations of the investigated plants species and their contents at the two sampling sites, surface and sub-surface soil, in their habitats during two seasons.

a- At surface soil

\begin{tabular}{|c|c|c|c|c|c|c|c|c|}
\hline \multirow{3}{*}{ Plant species } & \multicolumn{8}{|c|}{ Measured ions } \\
\hline & \multicolumn{2}{|c|}{$\mathrm{Cl}^{-}$} & \multicolumn{2}{|c|}{$\mathrm{SO4}^{2-}$} & \multicolumn{2}{|c|}{$\mathrm{Na}^{+}$} & \multicolumn{2}{|c|}{$\mathbf{K}^{+}$} \\
\hline & winter & summer & winter & summer & Winter & summer & winter & summer \\
\hline Z. coccineum & $-0.941^{* * *}$ & $0.806^{* *}$ & $-0697^{* * *}$ & 0.246 & -0.270 & $0.873^{* *}$ & $-0.74^{* *}$ & $0.937^{* *}$ \\
\hline S. imbricata & $-0.457-$ & $0.851^{* * *}$ & $0.650^{*}$ & 0.226 & 0.445 & $0.571^{*}$ & $0.753^{* *}$ & -0.380 \\
\hline S. monoica & -0.475 & 0.019 & -0.361 & $0.680^{* *}$ & -0.256 & -0.626 & $0.689^{*}$ & $* 0.777^{*}$ \\
\hline C. cretica & 0.36 & 0.3 & $0.859^{* *}$ & $-0.943^{* *}$ & 0.563 & $0.698^{*}$ & $0.894^{* *}$ & $0.643^{*}$ \\
\hline
\end{tabular}

* Significance level at $p<0.05 ; * *$ Significance level at $p<0.01$

b- At sub-surface soil

\begin{tabular}{|c|c|c|c|c|c|c|c|c|}
\hline \multirow{3}{*}{ Plant species } & \multicolumn{8}{|c|}{ Measured ions } \\
\hline & $\mathrm{Cl}^{-}$ & $\mathrm{SO}_{4}{ }^{2-}$ & $\mathrm{Na}^{+}$ & $\mathbf{K}^{+}$ & $\mathrm{Cl}^{-}$ & $\mathrm{SO}_{4}{ }^{2-}$ & $\mathrm{Na}^{+}$ & $\mathbf{K}^{+}$ \\
\hline & winter & summer & winter & summer & winter & summer & winter & summer \\
\hline Z. coccineum & $-0.927^{* *}$ & $0.635^{*}$ & $0.740^{* * *}$ & 0.279 & -0.203 & $0.841^{* *}$ & $0.773^{* *}$ & $0.918^{* * *}$ \\
\hline S. imbricata & $-0.659^{* *}$ & $0.724^{* * *}$ & $0.520^{*}$ & -0.025 & -0.137 & 0.438 & 0.297 & -0.286 \\
\hline S. monoica & -0.39 & 0.158 & 0.336 & 0.59 & -0.065 & -0.641 & $-0.780^{*}$ & $0.836^{* *}$ \\
\hline C. cretica & -0.612 & -0.235 & 0.054 & $0.923^{* *}$ & -0.163 & -0.599 & $0.672^{*}$ & $0.682^{*}$ \\
\hline
\end{tabular}

* Significance level at $p<0.05$;* Significance level at $p<0.01$

Table (7): Average values of total osmotic potential (-MPa) and partial osmotic potential ratios of ion participation, represented in percentage $(\%)$, in tested species at both seasons.

\begin{tabular}{|c|c|c|c|c|c|c|c|c|c|}
\hline \multirow{3}{*}{ Plant Species } & \multirow{3}{*}{ Season } & \multicolumn{8}{|c|}{ Measured Parameters } \\
\hline & & $\mathbf{T O P}^{\dagger}$ & $\begin{array}{l}\text { Osmotic } \\
\text { potential } \\
\text { of } \mathrm{NaCl}\end{array}$ & $\begin{array}{l}\text { POP }^{\ddagger} \\
(\%)\end{array}$ & $\begin{array}{l}\text { Cation } \\
\text { osmotic }\end{array}$ & $\begin{array}{l}\mathbf{A O P}^{\dagger \dagger} \\
\text { ratio }\end{array}$ & TOP & $\begin{array}{l}\text { Osmotic } \\
\text { potential } \\
\text { of } \mathrm{NaCl}\end{array}$ & $\operatorname{POP}(\%)$ \\
\hline & & (-MPa) & (-MPa) & $\mathrm{Na}^{+}$ & $\mathbf{K}^{+}$ & $\mathrm{Cl}^{-}$ & $\mathrm{SO}^{-2}$ & $\mathrm{Na}^{+} / \mathrm{K}^{+}$ & $\mathrm{Cl}^{-} / \mathrm{SO}_{4}{ }^{-2}$ \\
\hline \multirow{2}{*}{ Z. coccineum } & Winter & 6.75 & 1.55 & 17 & 6.0 & 6 & 1.0 & 2.83 & 6.0 \\
\hline & Summer & 4.80 & 2.35 & 19 & 2.0 & 30 & 1.0 & 9.5 & 30.0 \\
\hline \multirow{2}{*}{ S. imbricata } & Winter & 8.85 & 2.74 & 27 & 6.0 & 4 & 1.0 & 4.5 & 4.0 \\
\hline & Summer & 6.45 & 2.84 & 31 & 6.0 & 13 & 2.0 & 5.17 & 6.5 \\
\hline \multirow{2}{*}{ S. monoica } & Winter & 7.65 & 2.52 & 29 & 4.0 & 4 & 0.5 & 7.25 & 8.0 \\
\hline & Summer & 7.20 & 4.68 & 36 & 2.0 & 29 & 1.0 & 18.0 & 29 \\
\hline \multirow{2}{*}{ C. cretica } & Winter & 8.25 & 2.56 & 23 & 12.0 & 8 & 1.0 & 1.92 & 8.0 \\
\hline & Summer & 11.4 & 8.78 & 35 & 7.0 & 42 & 2.0 & 5.0 & 21.0 \\
\hline
\end{tabular}

${ }^{\dagger}$ TOP, Total osmotic potential; ${ }^{\ddagger} \mathrm{POP}$, Partial osmotic potential of ion participation; ${ }^{\dagger \dagger} \mathrm{AOP}$ ratio, Anion osmotic potential ratio. 


\section{DISCUSSION}

The water consumption by natural plants depends on the volume of water available to the roots. In this study, soil water content (SWC) was higher in winter than in summer in both surface and sub-surface soils. Apparently, the statistical analyses showed that changes in the season had the dominant effect on soil water content at soil surface, while the location factor had the dominant role on SWC in sub-surface soil. Moreover, the correlation analyses between the relative water content of plants and soil water suggested that the investigated species have a different response to water availability in the soil. $Z$. coccineum (during winter) showed positive correlations at the two soil depth levels. However, S. imbricata had negative correlations at both levels during winter. This indicates that, the investigated species may have different mechanisms for water conservation.

Clearly, many plants adjusted osmotically to soil salinity by accumulating ions. Under moderate levels of stress, roots may still actively absorb inorganic ions (potassium, calcium, sodium, magnesium, chloride, and others) from the soil (Amede and Schubert, 2003). This accumulation of mineral ions such as $\mathrm{K}^{+}, \mathrm{Na}^{+}, \mathrm{Cl}^{-}$, and $\mathrm{SO}_{4}{ }^{2-}$ facilitate osmotic adjustment of plants under atmospheric aridity and soil dryness (Farghali, 1998). Both sodium and chloride ions mostly increase in the vacuolar osmotic concentrations in plants under water stress. In general, the concentration of $\mathrm{Cl}^{-}$and $\mathrm{Na}^{+}$in surface soil studied was greater than in the sub-surface in both seasons, may be due to high water evaporation, while the concentration of $\mathrm{SO}_{4}{ }^{2-}$ is very low at both soil depths in the two seasons. Also, the data indicate that $\mathrm{Na}^{+}$is the most abundant cation in soil, having the highest concentration among other cations. The high concentration of $\mathrm{Na}^{+}$ions in soils may be probably due to the concentration decrease of other ions (Silberbrush and Ben-Asher, 2001), or may be as a result of interaction with other environmental factors, such as drought, which exaggerates the problems of $\mathrm{Na}^{+}$ toxicity. Other ions deficiency can occur because increased $\mathrm{Na}^{+}$inhibits the uptake of such nutrients by 1. disrupting the uptake of nutrients directly by interfering with transporters in the root plasma membrane, such as $\mathrm{K}^{+}$-selective ion channels; and 2. inhibiting root growth, by the osmotic effect of $\mathrm{Na}^{+}$and because of the detrimental effects of $\mathrm{Na}^{+}$on soil structure (Katschnig et al., 2015).

Apparently, the accumulation of different ions in tested species was affected by seasonal variations. In general, the plants had a tendency to accumulate $\mathrm{Cl}^{-}$, $\mathrm{SO}_{4}{ }^{2-}$, in summer. In some species especially, $C$. cretica, $S$. monoica, and succulent $Z$. coccineum a high concentration of $\mathrm{Cl}^{-}$is detected. This means that, the accumulation of $\mathrm{Cl}^{-}$may occur due to its major osmotic contribution to the solute in the vacuole and its involvement in both turgor and osmoregulation. In the cytoplasm, chloride regulates the activities of enzymes, also it acts as a counter anion and its fluxes are implicated in the stabilization of membrane potential, the regulation of $\mathrm{pH}$ gradients and electrical excitability (White and Broadley, 2001). Also, euhalophytes such as $C$. cretica, $S$. imbricata accumulate $\mathrm{SO}_{4}{ }^{2-}$ to maintain their succulence which is usually associated with the increase of sulphate content.

It was found that, high concentrations of $\mathrm{K}^{+}$, and $\mathrm{Na}^{+}$in most studied species were detected during winter. Furthermore, sodium ion was accumulated excess than $\mathrm{K}^{+}$accumulation and both cations were found at high levels in halophytes (Salsola, Cressa, and Suaeda). This means that, the increase of $\mathrm{Na}^{+}$levels may affect intercellular $\mathrm{K}^{+}$accumulation. From our point of view, the accumulation of $\mathrm{Na}^{+}$and $\mathrm{K}^{+}$found in such halophytes may play an important role in osmotic adjustment. Thus, the ionic osmotic potential in the studied species was mainly related to $\mathrm{K}^{+}$followed by $\mathrm{Na}^{+}$to tolerate the water stress and higher temperatures. It is found that, such plants could be adapted to drought stress, which might reflect their sensitivity to $\mathrm{Na}^{+}$toxicity by an accumulation of $\mathrm{K}+$ ions. Accordingly, the mechanisms of osmotic adju-stments of some xerophytes mainly depending on the accumulation of $\mathrm{K}^{+}$and/or sharing with $\mathrm{Na}^{+}$ions (Farghali and El- Aidrous,2016). Our findings agree with the work performed by Song et al., (2006) that $\mathrm{Na}^{+}$may contribute to osmoregulation in Suaeda species under both saline and arid environments. However, Glenn et al., (1996) pointed out that $\mathrm{K}^{+}$is accumulated in response to soil water deficit while $\mathrm{Na}^{+}$is accumulated under saline conditions. This indicates that, $\mathrm{K}^{+}$ion is not only an essential element for plant growth and development, but also a primary osmoticum in maintaining low water potential for plant tissues (Wang et al., 2004).

In this respect, plants have evolved remarkable mechanisms to regulate $\mathrm{K}^{+}$and $\mathrm{Na}^{+}$tissue and cellular homeostasis under salt stress (Almeida et al., 2017and Zhang et al., 2018). Really, $\mathrm{Na}^{+}$is accumulated in vacuoles to maintain low cellular osmotic water potential, whereas most of $\mathrm{K}^{+}$is concentrated in the cytosol to maintain the osmotic balance between cytoplasm and vacuole. Therefore, ion accumulation may be one of the most effective strategies for the adaptation of studied species to arid environments.

The ANOVA test clarified that seasons have the dominant role in regulating $\mathrm{Cl}^{-}$and $\mathrm{SO}_{4}{ }^{2-}$ concentration in most species. This indicates that sulphate taken up by the plant, which is in surplus to immediate requirements for growth, is stored in the vacuole. This means that, the effectiveness of mobilization of this vacuolar sulphate pool varies, and may reflect species differences or the ability of remobilization processes to keep pace with growth rates (Hawkesford, 2000). The seasonality has the dominant effect on $\mathrm{Na}^{+}$, and $\mathrm{K}^{+}$concentration in halophytes $S$. monoica and $C$. cretica, whereas both ions were affected by the interaction ( $\mathrm{S} \times \mathrm{L}$ ) in the case of $Z$. coccineum. Also, halophytes investigated had lower osmotic potential than xerophytes. The total osmotic potential was lower in summer than in winter in the majority of plants. 
In general, the osmotically adjusted species mainly accumulate solutes depending on the seasonal and species variations. Hence, the ionic osmotic potential (IOP) and/or the relative water content (RWC) in plants are related to solutes such as $\mathrm{Cl}^{-}, \mathrm{Na}^{+}$, and $\mathrm{K}^{+}$in to tolerate the water stress under hot air conditions. However, the significant negative correlation between both Ionic osmotic potential and RWC probably means that the concentration of the solutes decreases during the increase of RWC and vice versa. Whereby, such plants can be adapted to drought injury and thus differ in their mechanisms of osmotic adjustment in response to prevailing stresses, e.g. in $Z$. coccineum and $S$. imbricata, which may reflect their sensitivity to the toxic ions $\left(\mathrm{Na}^{+} \& \mathrm{Cl}^{-}\right)$and alternatively by increased binding of the water molecule (soluble proteins) to overcome the water loss. Finally, it is vital to differentiate solutes accumulation as a concentration effect from active osmotica using cell water volume of control plants before considering solute concentration as selection criteria for breading drought resistance varieties crops (Amede and Schubert, 2003).

\section{CONCLUSION}

The data hitherto, may be concluded the followings: 1.The greater absorption ratio attributed to increased $\mathrm{Na}^{+}$in the halophytic species indicate its capability to tolerate $\mathrm{Na}^{+}$toxicity; 2 . The selectivity of $\mathrm{Na}^{+}, \mathrm{K}^{+}$, and $\mathrm{Cl}^{-}$positively decrease the ionic water potential in plants, particularly in the hot season. The ionic osmotic water potential of $\mathrm{Na}^{+} / \mathrm{K}^{+}$and $\mathrm{Cl}^{-} / \mathrm{SO}_{4}^{-2}$ ratios are the promising screening tools for salt tolerance in studied species and halophytes in general.

\section{REFERENCES}

ALMEIDA, D. M.; OLIVEIRA, M. M. and SAIBO ,N. J. M. ( 2017).Regulation of $\mathrm{Na}^{+}$and $\mathrm{K}^{+}$homeostasis in plants: towards improved salt stress tolerance in crop plants. Genetics and Molecular Biology, 40(1): 326-345.

AMEDE T. and SCHUBERT S. (2003). Mechanisms of drought Resistance in grain legumes I: Osmotic adjustment. Ethiopian Journal of Science, 26(1):3746.

BLACK, C. A.; EVANS, D. D.; WHITE, J. L.; ENSMINGER, L. E. and CLARK, F. E. (1965). Methods of soil analysis. Part 2. ASA and SSSA 36 Madison, Wisconsin, USA.

BOULOS, L. (1999, 2000, 2002, 2005). Flora of Egypt Checklist.Vol.1, 2, 3 and 4 Al Hadara Publishing. Cairo-Egypt.

CHAVES, M.M., J. FLEXAS, and C. PINHEIRO. 2009. Photosynthesis under drought and salt stress: Regulation mechanisms from whole plant to cell. Annals of Botany 103:551-560.

EL-SHARKAWI, H.M. and ABDEL-RAHMAN, A.A. (1974). Response of olive and almond orchards to partial irrigation under dry forming practices in semi-arid region. II- plant soil water relations in olive during the growing season. Plant and Soil,
(Nether Lands), 31:13.

El-SHARKAWI, H.M. and SPRINGUEl, I.V. ( 1977). Germination of some crop plant seeds under reduced water potential. Seed Science and Technology, 5:677-688.

El-SHARKWI, H.M. and MICHEL B.E. (1977). Effects of soil water matric potential and air humidity on $\mathrm{CO} 2$ and water vapour exchange of two grasses. Photosynthetica, 11:176.

FARGHALI, K. A. (1998). Some physiological adaptation in five desert perennials: seasonal changes in ionic and metabolic solutes. Bulletin faculty of Science, University of Assiut, 27:25-39.

FARGHALI K.A. and EL-AIDAROUS , ABEER A., (2016). Ions Relationships between Plant and Soil under Hot Desert Conditions. Catrina, 15 (1): 25 36.

GLENN, E.; PFISTER, R.; BROWN, J.J.; THOMPSON, T.L. and O'LEARY, J.(1996). Na and $\mathrm{K}$ accumulation and salt tolerance of Atriptex canescens (Chenopodiaceae) genotypes. American Journal of Botany, 83:997-1005.

HAWKESFORD M.J.( 2000). Plant responses to sulphur deficiency and the genetic manipulation of sulphate transporters to improve S-utilization efficiency. Journal of Experimental Botany, 51: 131-138.

JACKSON, M. L. (1967). Soil chemical analysis. New Delhi: Prentice Hall of India.

KATSCHNIG, D.; BLIEK, T.; ROZEMA J. and SCHAT H.( 2015). Constitutive high-level SOS1 expression and absence of HKT1;1 expression in the salt-accumulating halophyte Salicornia dolichostachya. Plant Sci. 234:144-154.

KRAMER, P.J. and BOYER, J.S., 1995: Water relations of Plants and Soils. Academic Press, Pp. 480.

OSTLE, B. (1963). Statistics in research. Iowa: Iowa State University Press, Ames.

PARDO, J. M., and RUBIO, F. (2011). "Na+ and K+ transporters in plant signaling" in Transporters and pumps in plant signaling. eds. M. Geisler and K. Venema (Berlin Heidelberg: Springer), 65-98.

PLOXINSKI, N. A.( 1969). Rucovod stropobiom etriidlya zootexni ov. zdatel stvo "Kolos" Moskow

ROY S.J., NEGRÃO S., TESTER M. (2014). Salt resistant crop plants. Current Opinion in Biotechnology 26: 115-124.

SILBERBRSH, M. and BEN-ASHER, J. (2001). Simulation study of nutrient uptake by plants from soilless cultures as affected by salinity build up and transpiration. Plant and soil, 233(1): 59-69.

SLAYTER, R.O. AND MCLIOROY, I.C.(1961). Practical Microclimatology. C.S.I.R.O. UNESCO.

SONG, J.; FENG, GU; TIAN, C-Y. and ZHANG, FS.(2006). Osmotic adjustment traits of Suaeda physophora, Haloxylon ammodendron and Haloxylon persicum in field or controlled conditions. Plant Science, 170:113-119.

SUZUKI K., YAMAJI N., COSTA A., OKUMA E., KOBAYASHI N. I.and KASHIWAGI T. (2016). OsHKT1; 4-mediated $\mathrm{Na}^{+}$transport in stems contri- 
bute to $\mathrm{Na}^{+}$exclusion from leaf blades of rice at the reproductive growth stage upon salt stress. BMC Plant Biol. 16:22.

TESTER, M. and DAVENPORT, R. (2003). Na ${ }^{+}$Tolerance and $\mathrm{Na}^{+}$transport in higher plants. Annals of Botany, 91(5): 503-527.

WALTER, H.(1949). Grundlagen der pflazen verlientung. Einfubrig in die pflanzen. Geographic fur stud-erends der Hochschulen, Standortslehre. Stuttgart, Ulmer.

WANG, S., WAN, C., WANG, Y., CHEN, H., ZHOU, Z., FU, H. and SOSEBEE, R. E.(2004). The characteristics of $\mathrm{Na}+, \mathrm{K}+$ and free proline distribution in several drought-resistant plants of the Alxa desert, China. of Arid Environments, 56(3): 525-539.

WEATHERLY, P.E. and BARRS, C. (1962). A re- examination of the relative turgidity technique for estimating water deficit in leaves. Australian Journal of Biological Science, 15:413-428.

WHITE, P.J. and BROADLY, M.R.(2001). Chloride in soils and its Uptake and Movements within the plant. Annals of Botany, 88:967-988.

WILLIAMS, V. and TWINE, S. (1960). Flame Photometric Method for sodium, potassium and calcium. In: Peach, K. \&. Tracey, M. V. (eds.) Modern Methods of Plant Analysis, Vol. 5, pp. 3-5. Berlin: Springer Verlag.

ZHANG, Y.; FANG, J.; Wu, X. and DONG, L.( 2018). $\mathrm{Na}^{+} / \mathrm{K}^{+}$Balance and Transport Regulatory Mechanisms in Weedy and Cultivated Rice (Oryza sativa L.) Under Salt Stress. BMC Plant Biology, 18 (375):1-14.

\title{
تقييم الاسموزية الايونية فى النباتات الصحراية الملحية العصيرية وغير العصيرية القاطنة للواحات الحارة
}

\author{
قطب عامر فرغلى1، الحسنين محمد الثرقاوى1، أحمد محمد توفيق² وسوزان أحمد تمام1

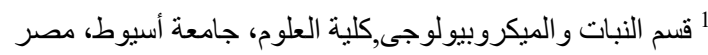

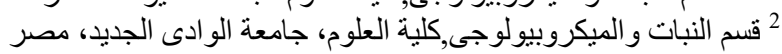 \\ الملخص العربى
}

هذه الدر اسة تم تتفيذها فى واحتى الخارجة والداخلة فى الصحر اء المصرية الغربية. الانواع النباتية قبد البحث اساسا لها أصول بيئية وصور

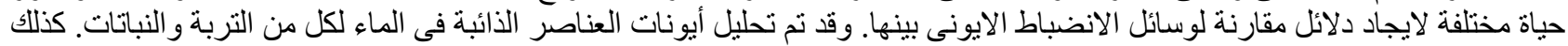

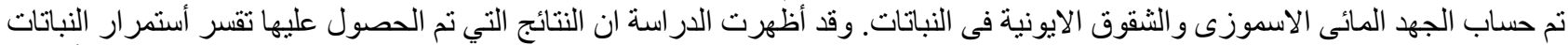

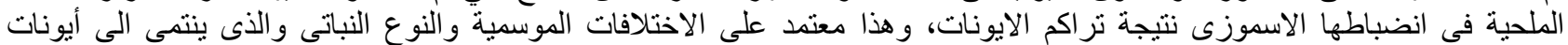

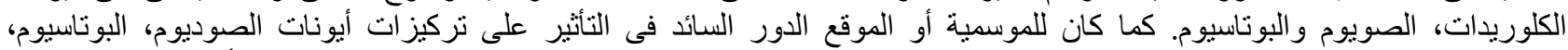

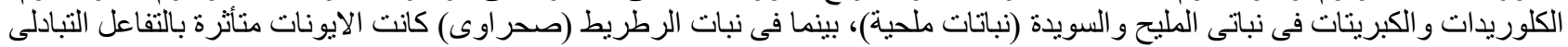

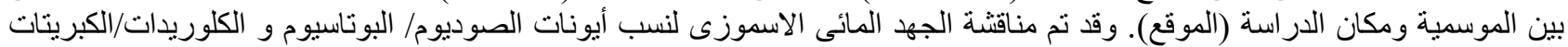

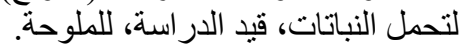

